\title{
Phylogenetic analysis of Gondwanan basal eusauropods from the Early- Middle Jurassic of Patagonia, Argentina
}

\author{
Femke M. HOLWERDA ${ }^{1,2, *}$ \& Diego $P O L^{3,4}$
}

${ }^{1}$ Staatliche Naturwissenschaftliche Sammlungen Bayerns (SNSB), Bayerische Staatssamlung für Paläontologie und Geologie, Ludwig-Maximilians-University Munich, Department for Earth and Environmental Sciences, Richard-Wagner-Strasse 10, 80333 München, Germany

${ }^{2}$ Faculty of Geosciences, Utrecht University, Heidelberglaan 2, 3584 CS Utrecht, The Netherlands; f.m.holwerda@gmail.com

${ }^{3}$ Consejo Nacional de Investigaciones Científicas y Técnicas (CONICET), Argentina

${ }^{4}$ Museo Paleontológico Egidio Feruglio, Avenida Fontana 140, Trelew, Argentina; dpol@mef.org.ar

* Corresponding author

Holwerda, F.M. \& Pol, D. 2018. Phylogenetic analysis of Gondwanan basal eusauropods from the Early-Middle Jurassic of Patagonia, Argentina. [Análisis filogenético de eusaurópodos basales de Gondwana del Jurásico Inferior-Medio de Patagonia, Argentina]. Spanish Journal of Palaeontology, 33 (2), 289-298.

\section{ABSTRACT}

Gondwanan Jurassic non-neosauropod eusauropods are key for the understanding of sauropod evolution, although their phylogenetic interrelationships remain poorly understood. However, following the revision of the holotype of a key taxon from the early Middle Jurassic Cañadón Asfalto Formation Patagonia, Argentina, Patagosaurus fariasi, the phylogenetic affinities need to be tested with new osteological information gathered during the redescription of the holotype of Patagosaurus. A new phylogeny presented here shows a close affiliation of Patagosaurus with Cetiosaurus from the Middle Jurassic of the UK. The close relationship of Patagosaurus with Barapasaurus, often found in previous phylogenies, was not recovered here. Instead, Patagosaurus is retrieved as more derived than most Early and Middle Jurassic sauropods, although more basal to Mamenchisaurus, Omeisaurus, turiasaurians, and neosauropods. Another sauropod taxon found together with Patagosaurus, Volkheimeria, is retrieved several nodes more basal than the former, which shows, together with evidence of several other sauropod taxa in

\section{RESUMEN}

Los eusaurópodos no neosaurópodos del Jurásico de Gondwana son especies clave para la comprensión de la evolución del clado Sauropoda, aunque sus relaciones filogenéticas siguen sin estar bien resueltas. Sin embargo, gracias a la revisión del holotipo de uno de los taxones más importantes del Jurásico Medio temprano de la Formación Cañadón Asfalto, Patagosaurus fariasi, bastantes de sus hipótesis filogenéticas han de ser puestas en duda, basadas en la nueva información osteológica recogida durante la redescripción del holotipo de Patagosaurus. La nueva hipótesis filogenética aquí presentada muestra una relación cercana entre Patagosaurus y Cetiosaurus, del Jurásico Medio del Reino Unido. La cercanía filogenética de Patagosaurus con Barapasaurus, publicada en numerosos análisis filogenéticos, no se obtuvo en este nuevo análisis. En este caso, Patagosaurus aparece como un taxón más derivado que la mayoría de saurópodos del Jurásico Medio y Superior, aunque más basal que Mamenchisaurus, Omeisaurus, Turiasauria y Neosauropoda. Otro taxón que se encuentra normalmente emparentado con Patagosaurus, 
the Cañadón Asfalto Formation, that a high evolutionary diversity existed in Southwest Gondwana in the early Middle Jurassic, a pattern which is also seen in fossil groups other than sauropods (e.g., theropods).

Keywords: Middle Jurassic, Gondwana, Patagonia, sauropod, phylogeny.
Volkheimeria, en nuestro análisis aparece varios nodos más basalmente que Patagosaurus. Esto muestra, junto con la presencia de otros taxones de saurópodos de la Formación de Cañadón Asfalto, que una diversidad evolutiva alta existió en el suroeste de Gondwana en el Jurásico Medio temprano, un patrón que también está presente en otros grupos fósiles (e.g., terópodos).

Palabras clave: Jurásico Medio, Gondwana, Patagonia, saurópodo, filogenia.

\section{INTRODUCTION}

Non-neosauropod sauropods are thought to have emerged in the Late Triassic of South Gondwana, although remains of a basal sauropod are known from possible Triassic sediments of Thailand (Buffetaut et al., 2000, 2002; Racey \& Goodall, 2009) and recently described ichnofossils suggest the presence of sauropods in the Late Triassic of Greenland (Lallensack et al., 2017). After their initial appearance in the fossil record, sauropods achieved a worldwide distribution by the Early Jurassic (Raath, 1972; Jain et al., 1975; Cooper, 1984; McPhee et al., 2015, 2016), with non-neosauropod eusauropods first appearing in the fossil record in the early Middle Jurassic of Gondwana and Laurasia, with most material coming from South America (e.g., Patagosaurus, Volkheimeria) (Bonaparte, 1979, 1986a), Africa (e.g., Spinophorosaurus, Lapparentosaurus, Bothriospondylus) (Bonaparte, 1986b; Läng, 2008; Remes et al., 2009; Mannion, 2010), and India (e.g., Barapasaurus) (Jain et al., 1975; Bandyopadhyay et al., 2010). Other forms are known from Europe (e.g. Cetiosaurus and Asia (e.g. Shunosaurus) (Zhang, 1988) but they are found in younger sediments of late Middle Jurassic age, or even early Late Jurassic (Wang et al., $2018)$. By the Late Jurassic boundary ( 150Ma) all major clades were established (McIntosh, 1990; Upchurch et al., 2004; Barrett \& Upchurch, 2005; Wilson, 2005). The Gondwanan taxa are especially important for the study of sauropod evolution, as they are represented by the most complete record to date of early eusauropod body fossils. Patagosaurus fariasi is one of the best-preserved taxa with a plethora of referred material (Bonaparte, 1986a) found in two localities of the Cañadón Asfalto Formation near the Cerro Cóndor village in central Patagonia, Argentina. Though used in many phylogenies, it has not received much revision since it was named and first described in 1979 and 1986 by Bonaparte, and therefore its current phylogenetic position is unclear. Moreover, the strata from whence Patagosaurus and Volkheimeria were unearthed contain at least three other (as yet unnamed) sauropod taxa (Pol et al., 2009; Rauhut, 2003a; Holwerda et al., 2015;
Becerra et al., 2017; Carballido et al., 2017). This shows a higher taxic diversity than elsewhere in Gondwana or Laurasia in contemporaneous beds. Finally, the Cañadón Asfalto Formation has recently been redated and found to be much older than previously assumed; roughly ranging between Toarcian-Bajocian (Cúneo et al., 2013), placing the fossils from the Cañadón Asfalto Formation right at the time of the early eusauropod diversification and radiation (Bonaparte, 1986b; Barrett \& Upchurch, 2005; Cúneo et al., 2013).

Traditionally, Patagosaurus is retrieved as a basal eusauropod, more derived than Shunosaurus, and more basal to Mamenchisaurus, Omeisaurus, turiasaurians and neosauropods (see, for instance, Upchurch, 1998; Wilson, 2002; Harris, 2006; Carballido et al., 2011, 2012). In some phylogenetic analyses, Patagosaurus has come out either as sister taxon to the Indian Early-Middle Jurassic taxon Barapasaurus or the Middle Jurassic Cetiosaurus from the UK (Allain \& Aquesbi, 2008; Remes et al., 2009). Other phylogenies recover Patagosaurus as more derived than either Barapasaurus or Cetiosaurus or one or other as more/less derived. The analysis of Läng \& Mahammed (2010) recovers Patagosaurus as more derived than Barapasaurus, Cetiosaurus oxoniensis, and Cetiosaurus mogrebiensis, but more basal to the Rutland Cetiosaurus. The differing results of several phylogenies, which incorporate more basal sauropods reflect on the paucity of information on Early and Middle Jurassic sauropods.

Bonaparte (1986a) traditionally grouped Barapasaurus, Cetiosaurus and Patagosaurus together as 'cetiosaurs' based on morphological similarities, primarily in posterior dorsal vertebrae. With new information on the osteology of Patagosaurus, these relationships can be revisited. Volkheimeria, found together with Patagosaurus in the Cerro Cóndor localities, Patagonia, Argentina, was thought to be closely related to the Malagasy taxon Lapparentosaurus by Bonaparte (1986a, 1986b), however, in some phylogenies Volkheimeria is retrieved as more basal than Patagosaurus (e.g., Pol et al., 2011) and Lapparentosaurus has rarely been included in phylogenetic datasets, save for the analyses of Läng (2008) and Mannion 
et al. (2013). Recoding these specimens may further elucidate the interrelationships of Gondwanan eusauropods, which in turn will aid in sauropod evolutionary and biogeographical research.

Here, we present a new phylogenetic analysis focusing on Jurassic Gondwanan sauropods, together with an updated systematic review of all major Jurassic sauropod taxa that provide osteological information for phylogenetic analysis.

\section{METHODS}

\subsection{Coding}

Coding was done based on first-hand observations of the holotype of Patagosaurus (Instituto Miguel Lillo, Tucuman, Argentina), Cetiosaurus oxoniensis (OUMNH, Oxford, UK) and the Rutland Cetiosaurus (New Walk Museum and Art Gallery, Leicester, UK), Lapparentosaurus (MNHN, Paris, France), Amygdalodon (Museo de La Plata, Argentina), Bothriospondylus (NHM, London), Cetiosauriscus (NHM, London), Tazoudasaurus (MNHN, Paris), Spinophorosaurus and Jobaria (NMB, Naturhistorisches Museum Braunschweig, Braunschweig, Germany). All other sauropods in this matrix were coded using photographs, publications and information from previous matrices.

The matrix used is based on Carballido et al. (2012), to which characters were added by McPhee et al. (2014) as well as new characters which were added by the authors. See Supplementary Data for a list of characters and their coding.

\subsection{Software}

The data matrix was coded using Mesquite version 2.75 (Maddison \& Maddison, 2010).

The resulting data matrix was analysed in TNT (Goloboff et al., 2008) in TNT version 1.5 (Goloboff \& Catalano, 2016).

\section{RESULTS}

\subsection{Systematic revision of Middle Jurassic Gondwanan sauropods}

An updated systematic overview of several relatively well represented Early and Middle Jurassic sauropods used in this analysis is given below.
Patagosaurus fariasi was found in the late 70's and early 80's, it was named in 1979 and more fully described in 1986 (Bonaparte, 1979, 1986a). Several specimens were found from two localities, Cerro Cóndor Norte (which yielded the holotype specimen) and Cerro Cóndor Sur, both in the Cañadón Asfalto Formation, west-central Chubut Province, Patagonia, Argentina. The age is probably Aalenian-Bajocian, which is significantly older than the original Callovian age given (Bonaparte, 1986a; Cúneo et al., 2013). It is now believed that the material originally assigned to Patagosaurus includes at least one other taxon, and, possibly, two further taxa (MACN-CH 934, MACNCH 230; Rauhut, 2003a). For this analysis, however, only the holotype PVL 4170 is coded.

Barapasaurus tagore $i$ is an Indian taxon from the Early Jurassic Kota Formation, Pranhita-Godavari basin, Deccan, India (Bandyopadhyay et al., 2010). It was first described in the 1970's (Jain et al., 1975; Jain, 1980) and was recently redescribed (Bandyopadhyay et al., 2010). Next to the basal sauropod Kotasaurus (Yadagiri, 2001; Kutty et al., 2007), it is the only Indian Early Jurassic taxon known to date, and is therefore important for the study of Gondwanan sauropod evolution. It is known from several specimens, and includes teeth, as well as axial and appendicular material including pelvic and pectoral elements.

Cetiosaurus oxoniensis is historically speaking the oldest sauropod to be described, despite being deliberately omitted from the first paper naming Dinosauria, as it was thought to be a marine animal. Although not completely described until 1871 (see Owen, 1841, 1842; Phillips, 1871; Upchurch \& Martin, 2003; Taylor, 2010), its first description dates from 1841 (the same year that Cardiodon was first described but based only on an isolated tooth (Owen, 1841; Taylor, 2010). The genus has, unfortunately, become a wastebasket for many nomina dubia and nomina nuda over the years. The type species under ICZN regulations was Cetiosaurus medius, which is a very incomplete series, however in 2009 the Cetiosaurus specimen known as the Bletchingdon specimen, from near Oxford, which is a large individual with many more skeletal elements than $C$. medius, was designated as the type species after an ICZN case was made (Taylor, 2010; Upchurch et al., 2009; Upchurch \& Martin, 2003). It is from the Forest Marble of Oxfordshire, UK, which is Bathonian in age $( \pm 168 \mathrm{Ma})$. The specimen includes a caudal series, one partial cervical, a partial dorsal, and many appendicular elements, as well as pectoral and pelvic elements.

The "Rutland Cetiosaurus" is a sauropod found in Rutland, Leicestershire, UK, in 1968 in a brick pit, the sediments of which are dated as upper Bajocian $( \pm 175$ $\mathrm{Ma}$ ). The specimen is the most complete sauropod from the UK to date, consisting of a well-preserved cervical and dorsal series, several caudals, and several (though more 
fragmentary) appendicular elements. It was originally ascribed to Cetiosaurus oxoniensis (Upchurch \& Martin, 2002), however, recently several differences have been found between the Rutland Cetiosaurus and Cetiosaurus oxoniensis, which could mean that the Rutland Cetiosaurus is in fact a different species from C. oxoniensis, which has previously been proposed (Läng, 2008).

Volkheimeria chubutensis is a sauropod from the locality of Cerro Cóndor Sur, Cañadón Asfalto Formation, westcentral Chubut, Patagonia, Argentina. It is known from several vertebral and appendicular elements, as well as pelvic elements. It was found together with Patagosaurus, and described in 1979 and 1986 by Bonaparte.

Amygdalodon patagonicus is an Early Jurassic sauropod from Patagonia, Argentina. It was found in the Cerro Carnerero Formation at Pampa Agnia, Patagonia, Argentina, which was thought to be Bajocian, but may be as old as Pliensbachian-Toarcian (see Rauhut, 2003a; Cúneo et al., 2013). It was first described in 1947 (Cabrera, 1947), redescribed in three subsequent papers (Casamiquela, 1963; Rauhut, 2003b; Carballido \& Pol, 2010). The material consists of isolated teeth, several appendicular elements and some fragmentary axial elements. It has been retrieved as a sauropod basal to Tazoudasaurus, Vulcanodon, and eusauropods. The dentition, in particular the enamel wrinkling pattern, thus far has been found to be unique amongst other basal sauropods ( Carballido \& Pol, 2010).

Tazoudasaurus naimi was found in the High Atlas Mountains in Morocco, North Africa, from the Azilal/ Wazzant Formation, which is thought to be Toarcian to Aalenian in age, with Tazoudasaurus coming most probably from the Toarcian layers (Allain et al., 2004; Allain \& Aquesbi, 2008). It is known from several individuals, both juveniles and adults, which sheds light on early sauropod ontogenetic variation. The material consists of dentition, cranial, axial, and appendicular material. A reconstruction of Tazoudasaurus has also been recently attempted (Peyer \& Allain, 2010).

Spinophorosaurus nigerensis is a recently described basal eusauropod from the Middle Jurassic of Niger, Africa (Remes et al., 2009). It is known from several specimens, most of which are still under preparation. A full osteology is currently in the making (F. Knoll, pers. comm.). The holotype consists of several axial elements, cranial elements, teeth, and several pectoral, pelvic and appendicular elements. A braincase was described in 2012, drawing attention to a combination of primitive and derived characters (Knoll et al., 2012), which is not unusual for basal eusauropods. Lastly, this sauropod is peculiar for Jurassic sauropods in that it probably possessed tail spines (Remes et al., 2009).

Shunosaurus lii was found in 1977, named in 1983 and further described in 1988 (Dong et al., 1983; Zhang, 1988). It was found in the Lower Xiashaximiao Formation near Dashanpu, Zigong, China, which was thought to be Bathonian to Oxfordian in age ( $\pm 168-157 \mathrm{Ma})$, however, recent redating of the depositional sediments yields a maximum age of $159 \pm 2 \mathrm{Ma}$, giving it an Oxfordian age (Wang et al., 2018). It is the most common sauropod from the Xiashaximiao Formation. It was thought to be a euhelopodid sauropod by Upchurch $(1995,1998)$, however, Wilson (2002) retrieved it as a basal eusauropod. A redescription of cranial material was published more recently, which found a unique curvature in both the maxillae as well as the dentaries (Chatterjee \& Zheng, 2002; Zheng, 1996). A more recent description of the postcranial material, however, has not been performed. More redescriptions of Chinese sauropods from the Middle Jurassic will give more information on the phylogenetic position of Shunosaurus. Currently, it is usually found at the base of the eusauropods, being more basal than Cetiosaurus, Patagosaurus, and all other sauropods, but more derived than Vulcanodon, Tazoudasaurus, Amygdalodon, and Spinophorosaurus in phylogenetic analyses. Finally, it is peculiar amongst Jurassic sauropods due to the presence of a tailclub, something found otherwise (thus far) only in Spinophorosaurus, Mamenchisaurus, and potentially Kotasaurus (Xing et al., 2009; Ouyang \& Ye, 2002; Remes et al., 2009).

Mamenchisaurus is a generic name for many different species, the most important for this study being Mamenchisaurus youngi and Mamenchisaurus hochuanensis (Young \& Zhao, 1972; Russell \& Zheng, 1993; Pi et al., 1996; Ouyang \& Ye, 2002). The Mamenchisauridae is a group of Laurasian sauropods with extreme neck elongation, and their remains have been found in China, Thailand, and Mongolia (Suteethorn et al., 2012; Xing et al., 2015). The Mamenchisaurus fauna, unlike the Shunosaurus-Omeisaurus fauna, is Middle Jurassic in age (Wang et al., 2018). Their interrelationships are a work of ongoing progress, as in many eusauropod phylogenies they emerge as more derived than most derived non-neosauropod eusauropods, like Cetiosaurus and Patagosaurus (e.g., Wilson, 2002; Upchurch et al., 2004; Allain \& Aquesbi, 2008; Remes et al., 2009). This could, however, be due to only one species of Mamenchisaurus generally being used for sauropod phylogenies (and then it usually is retrieved as sister-taxon to Omeisaurus) since within a mamenchisaurid-based phylogeny they are retrieved as more basal than most nonneosauropod eusauropods (Xing et al., 2015).

Omeisaurus is a generic name for species that include Omeisaurus maoianus, Omeisaurus junghsiensis, and many others. It was found in the Shaximiao Formation of Sichuan Province, China, which was dated to the Bathonian-Callovian $( \pm 178-168 \mathrm{Ma})$, however, like Shunosaurus, it is recently found to be Oxfordian in age $(159 \pm 2 \mathrm{Ma})$ (Wang et al., 2018). It was first described in 1939 , and more specimens were added to the genus in the 1970's and 1980's, several of them supposedly representing 
different species. The most recent descriptions are from the early 2000's, however (Young, 1939; Dong et al., 1983; He et al., 1984, 1988; Tang et al., 2001; Wings et al., 2011).

\subsection{Phylogeny}

The matrix used consists of 350 characters and 75 taxa. Pruning was done for unstable taxa after the tree searches by using IterPCR (Pol \& Escapa, 2009; Goloboff \& Szumik, 2015). Taxa to be pruned a-posteriori were Cetiosauriscus stewarti and Klamelisaurus gobiensis. Both sauropod taxa are either in need of revision or are currently under revision (see Heathcote \& Upchurch, 2003; Moore et al., 2017). The resulting consensus tree with Bremer support is shown in Figure 1.

Patagosaurus is retrieved as sister taxon to the Rutland Cetiosaurus, and nested within Cetiosaurus, (see Table 1 for a list of synapomorphies). Furthermore, Barapasaurus, the other 'cetiosaur', is retrieved as less derived, being sistertaxon to the node of Spinophorosaurus +Volkheimeria, which all together are more basal to Shunosaurus and Patagosaurus + Cetiosaurus. Moreover, it takes 14 steps to force Barapasaurus to nest within Cetiosaurus oxoniensis and it takes 15 extra steps for it to go into a sistergroup with Patagosaurus and the Rutland Cetiosaurus (Table 2). In a previous analysis by Remes et al. (2009), Patagosaurus + Barapasaurus were only one step away from the shortest trees. The main characters that differ between Patagosaurus and Barapasaurus are the ventral surface of the dorsal centra (ch.153) and the projection of the neural spine of anterior caudal vertebrae (ch.221). Spinophorosaurus, on the other hand, needs only two steps to be nested with Cetiosaurus, and 3 steps to be sister taxon to Patagosaurus. Other than this, the tree does not change much from previous analyses, in that Tazoudasaurus and Vulcanodon come out as sister-taxa, and more basal to Barapasaurus, as was previously also found (Allain \& Aquesbi, 2008; Läng, 2008). Patagosaurus is also still found to be more basal to mamenchisaurs, turiasaurians, and neosauropods, which was also found in previous analyses (e.g., Wilson, 2002; Harris, 2006; Carballido et al., 2012, 2015; Carballido \& Sander, 2014) Neosauropoda. However, the re-coding of Volkheimeria retrieves this taxon as more basal than Patagosaurus, forming a sister-group with the North African Middle Jurassic taxon Spinophorosaurus. In the current analysis, only takes one additional step to undo this grouping, however, it takes eleven steps to force Volkheimeria as sister taxon to Patagosaurus. Volkheimeria was recovered as a basal sauropod in a previous analysis (Pol et al., 2011) however, in the 2011 analysis it was recovered as more derived than Shunosaurus, and more basal than Lapparentosaurus, Barapasaurus, Omeisaurus, and Patagosaurus.

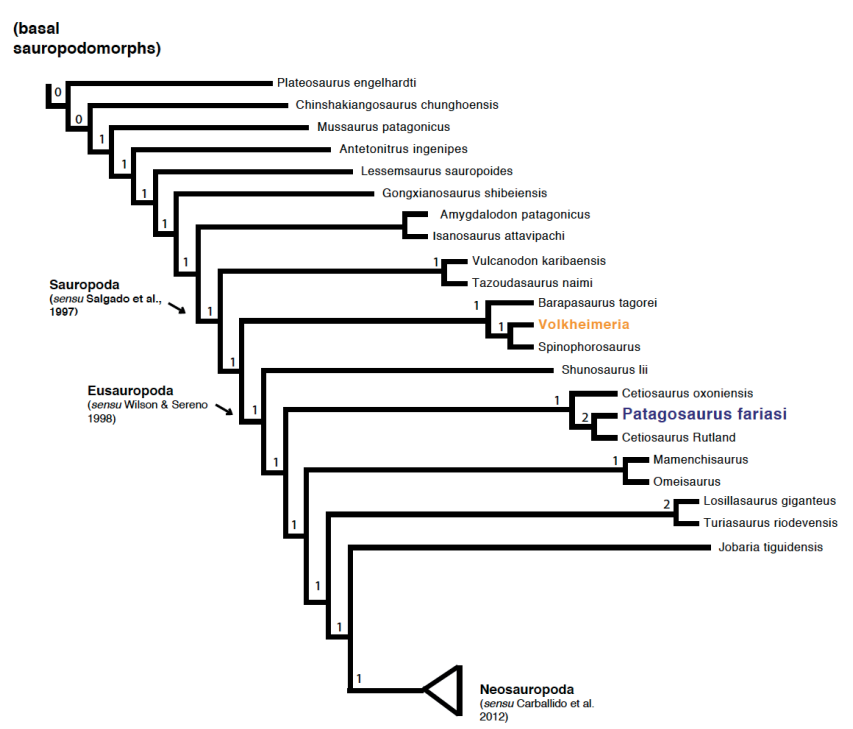

Figure 1. Consensus tree with Bremer support, Patagosaurus highlighted in blue and Volkheimeria highlighted in yellow.

Table 1. List of synapomorphies for Patagosaurus and other nodes.

\begin{tabular}{|c|c|}
\hline Node & Synapomorphies \\
\hline $\begin{array}{l}\text { Spinophorosaurus } \\
+ \text { Volkheimeria }\end{array}$ & $\begin{array}{l}\text { 155: weakly developed hyposphene-hypanthrum } \\
\text { complex on posterior dorsals }\end{array}$ \\
\hline \multirow{2}{*}{$\begin{array}{l}\text { Barapasaurus }+ \\
\text { eusauropods }\end{array}$} & 108: presence of longitudinal grooves on teeth \\
\hline & $\begin{array}{l}\text { 175: height of pedicels of middle and posterior } \\
\text { dorsal postzygapophyses subequal or higher than } \\
\text { centrum }\end{array}$ \\
\hline \multirow{4}{*}{$\begin{array}{l}\text { Patagosaurus } \\
+ \text { Rutland } \\
\text { Cetiosaurus }\end{array}$} & 123: Complex pleurocoel on cervical centra \\
\hline & $\begin{array}{l}\text { 134: laterally expanded neural spine on posterior } \\
\text { cervicals }\end{array}$ \\
\hline & 157: single tpol supporting hyposphene from below \\
\hline & 179: medial spol on posterior dorsals \\
\hline \multirow{4}{*}{$\begin{array}{l}\text { Cetiosaurus + } \\
\text { Patagosaurus } \\
+ \text { Rutland } \\
\text { Cetiosaurus }\end{array}$} & 164: pcpl absent on middle and posterior dorsals \\
\hline & $\begin{array}{l}\text { 165: slightly dorsoventrally compressed dorsal } \\
\text { centrum }\end{array}$ \\
\hline & $\begin{array}{l}\text { 175: height of pedicels of middle and posterior } \\
\text { dorsal postzygapophyses subequal or higher than } \\
\text { centrum }\end{array}$ \\
\hline & $\begin{array}{l}\text { 217: presence of ventral longitudinal hollow on } \\
\text { anterior and middle caudals }\end{array}$ \\
\hline \multirow{7}{*}{$\begin{array}{l}\text { Mamenchisaurus } \\
+ \text { eusauropods }\end{array}$} & 115: presence of pleurocoels within cervical centra \\
\hline & 137: 12 or more dorsal vertebrae \\
\hline & 138: pleurocoels in dorsal centra \\
\hline & 148: single neural spines on dorsal vertebrae \\
\hline & 174: dorsal contact of spdl +1 spol \\
\hline & 192: dorsoventral length sacral ribs \\
\hline & 238: size scapular acromion process \\
\hline
\end{tabular}


Table 2. number of steps required to move key taxa to other nodes or positions.

\begin{tabular}{|c|c|c|}
\hline Taxon & Moved to position/node & $\begin{array}{c}\text { n.o. extra } \\
\text { steps required }\end{array}$ \\
\hline Barapasaurus & Cetiosaurus oxoniensis & 12 \\
\hline Barapasaurus & $\begin{array}{l}\text { Patagosaurus }+ \text { Rutland } \\
\text { Cetiosaurus }\end{array}$ & 15 \\
\hline Barapasaurus & Sister taxon to Patagosaurus & 14 \\
\hline Barapasaurus & Spinophorosaurus + Volkheimeria & 8 \\
\hline Patagosaurus & $\begin{array}{l}\text { Sister taxon to Cetiosaurus } \\
\text { oxoniensis }\end{array}$ & 5 \\
\hline Spinophorosaurus & Cetiosaurus oxoniensis & 2 \\
\hline Spinophorosaurus & Sister taxon to Patagosaurus & 3 \\
\hline Spinophorosaurus & Sister taxon to Rutland Cetiosaurus & 5 \\
\hline Volkheimeria & $\begin{array}{l}\text { Patagosaurus }+ \text { Rutland } \\
\text { Cetiosaurus }\end{array}$ & 11 \\
\hline Volkheimeria & Sister taxon to Patagosaurus & 14 \\
\hline
\end{tabular}

\section{DISCUSSION}

Even though the phylogenetic position of Patagosaurus with respect to most non-neosauropod sauropods does not differ much in this analysis from previous analyses, the nesting of Patagosaurus within Cetiosaurus is an interesting new outcome of this phylogeny. This position does confirm the original assessment of Bonaparte (1986a), in that Patagosaurus and Cetiosaurus share a close phylogenetic affinity. Both are from roughly the same age; Patagosaurus from the early Middle Jurassic (likely Aalenian-Bajocian), Cetiosaurus oxoniensis from the Bathonian, and the Rutland Cetiosaurus being Bajocian in age (Cox et al., 1992; Upchurch \& Martin, 2002, 2003; Liston, 2004a, 2004b; Barrett, 2006; Noè, et al., 2010; Cúneo et al., 2013; Hauser et al., 2017). Further research, especially on the Rutland Cetiosaurus, might give more information on the precise relationships between these taxa and whether or not the 'cetiosaurs' as a group are in need of revision.

The separation of Patagosaurus and Barapasaurus by several steps is another new outcome of this analysis. The break-up of the Barapasaurus+Patagosaurus grouping has interesting biogeographical implications. Remes et al. (2009) suggested the Central Gondwanan Desert may be a biogegraphical barrier that isolated southern Gondwana and cited the sister-group relationship of Barapasaurus+Patagosaurus as lending support to this hypothesis. The new phylogenetic results do not support such a scenario and, furthermore, it also shows few extra steps are necessary to group Patagosaurus with the North
African taxon Spinophorosaurus. More osteological information on Spinophorosaurus may resolve this in the future.

The high diversity of sauropods in the Cañadón Asfalto Formation, shown here by Patagosaurus as a derived nonneosauropod eusauropod and Volkheimeria as a more basal sauropod, whilst both originating from the same bonebed, is compatible with a rapid regional diversification in the early Middle Jurassic, a pattern also noted for Jurassic theropods from Patagonia (Pol \& Rauhut, 2012). Finally, the presence of a derived eusauropod in the AalenianBajocian suggests an earlier sauropod diversification, which might be pushed back into the Early Jurassic or even to the Late Triassic. However, in order to investigate whether the early Middle Jurassic strata of Patagonia were a sauropod biodiversity 'hotspot', other sauropods from Gondwana require revision, such as Barapasaurus, Lapparentosaurus, Bothriospondylus and even Volkheimeria.

\section{CONCLUSIONS}

With this new analysis, Patagosaurus fariasi is retrieved as a derived non-neosauropodan eusauropod, more derived than most non-neosauropodan sauropods, and basal to (Mamenchisaurus + Omeisaurus, turiasaurians). It is retrieved as sister taxon to the Rutland Cetiosaurus, and as nested within Cetiosaurus. The analysis shows a high sauropod taxonomic and evolutionary diversity, which in turn points to a rapid regional diversification in the early Middle Jurassic of Patagonia, making South Gondwana an important site for sauropod evolution and radiation.

\section{ACKNOWLEDGEMENTS}

The authors would like to thank Jaime Powell (Instituto Lillo, Tucuman), Hillary Ketchum (OUMNH, Oxford), Mark Evans (New Walk Museum, Leicester), Sandra Chapman (NHM, London), Ronan Allain (MNHN, Paris), Ulrich Joger \& Ralf Kosma (SNHM, Braunschweig) for kind admission to the collections their museums. The authors are further indebted to José Luis Carballido, Emmanuel Tschopp and Phil Mannion for sharing collection images. Verónica Díez Díaz is thanked for her kind suggestions, comments and translations, as well as José Canudo, both of whose comments improved this paper. Finally, the authors acknowledge the Willi Hennig Society. FH was funded by the SEP AJISEP-2016 (SEPAI-2016-07313) grant. 


\section{REFERENCES}

Allain, R. \& Aquesbi, N. 2008. Anatomy and phylogenetic relationships of Tazoudasaurus naimi (Dinosauria, Sauropoda) from the late Early Jurassic of Morocco. Geodiversitas, 30, 345-424.

Allain, R., Aquesbi, N., Dejax, J., Meyer, C., Monbaron, M., Montenat, C. \& Taquet, P. 2004. A basal sauropod dinosaur from the Early Jurassic of Morocco. Comptes Rendus Palevol, 3, 199-208; doi: 10.1016/j.crpv.2004.03.001.

Bandyopadhyay, S., Gillette, D.D., Ray, S. \& Sengupta, D.P. 2010. Osteology of Barapasaurus tagorei (Dinosauria: Sauropoda) from the Early Jurassic of India. Palaeontology, 53, 533-569; doi: 10.1111/j.1475-4983.2010.00933.x.

Barrett, P.M. 2006. A sauropod dinosaur tooth from the Middle Jurassic of Skye, Scotland. Earth and Environmental Science Transactions of the Royal Society of Edinburgh, 97, 25-29; doi: 10.1017/S0263593300001383.

Barrett, P.M. \& Upchurch, P. 2005. Sauropodomorph diversity through time. In: The Sauropods: Evolution and Paleobiology (eds. Curry, R.K. \& Wilson, J.). Berkeley, CA, Univ. of California Press, 125-156.

Becerra, M.G., Gomez, K.L. \& Pol, D. 2017. A sauropodomorph tooth increases the diversity of dental morphotypes in the Cañadón Asfalto Formation (Early-Middle Jurassic) of Patagonia. Comptes Rendus Palevol, 16, 832-840; doi: 10.1016/j.crpv.2017.08.005.

Bonaparte, J.F. 1979. Dinosaurs: a Jurassic assemblage from Patagonia. Science, 205, 1377-1379; doi: 10.1126/ science.205.4413.1377.

Bonaparte, J.F. 1986a. Les dinosaures (Carnosaures, Allosauridés, Sauropodes, Cétosauridés) du Jurassique Moyen de Cerro Cóndor (Chubut, Argentina). Annales de Paléontologie (Vert.-Invert.), 72, 247-289.

Bonaparte, J.F. 1986b. The early radiation and phylogenetic relationships of the Jurassic sauropod dinosaurs, based on vertebral anatomy. In: The Beginning of the Age of Dinosaurs (ed. Padian, K.). Cambridge University Press, Cambridge, 247-258.

Buffetaut, E., Suteethorn, V., Cuny, G., \& Tong, H. 2000. The earliest known sauropod dinosaur. Nature, 407, 72.

Buffetaut, E., Suteethorn, V., Le Loeuff, J., Cuny, G., Tong, H. \& Khansubha, S. 2002. The first giant dinosaurs: a large sauropod from the Late Triassic of Thailand. Comptes Rendus Palevol, 1, 103-109; doi: 10.1016/S16310683(02)00019-2.

Cabrera, A. 1947. Un saurópodo nuevo del Jurásico de Patagonia. Notas Museo de La Plata Paleontología, 95, $1-17$.

Carballido, J.L. \& Pol, D. 2010. The dentition of Amygdalodon patagonicus (Dinosauria: Sauropoda) and the dental evolution in basal sauropods. Comptes Rendus Palevol, 9, 83-93; doi: 10.1016/j.crpv.2010.01.003.

Carballido, J.L. \& Sander, P.M. 2014. Postcranial axial skeleton of Europasaurus holgeri (Dinosauria, Sauropoda) from the Upper Jurassic of Germany: implications for sauropod ontogeny and phylogenetic relationships of basal Macronaria. Journal of Systematic Palaeontology, 12, 335-387; doi: 10.1080/14772019.2013.764935.
Carballido, J.L, Rauhut, O.W.M., Pol, D. \& Salgado, L. 2011. Osteology and phylogenetic relationships of Tehuelchesaurus benitezii (Dinosauria, Sauropoda) from the Upper Jurassic of Patagonia. Zoological Journal of the Linnean Society, 163, 605-662; doi: 10.1111/j.10963642.2011.00723.x.

Carballido, J.L., Salgado, L., Pol, D., Canudo, J.I. \& Garrido, A. 2012. A new basal rebbachisaurid (Sauropoda, Diplodocoidea) from the Early Cretaceous of the Neuquén Basin; evolution and biogeography of the group. Historical Biology, 24, 631-654; doi: 10.1080/08912963.2012.672416.

Carballido, J.L., Pol, D., Ruge, M.L.P., Bernal, S.P., PáramoFonseca, M.E. \& Etayo-Serna, F. 2015. A new Early Cretaceous brachiosaurid (Dinosauria, Neosauropoda) from northwestern Gondwana (Villa de Leiva, Colombia). Journal of Vertebrate Paleontology, 35, e980505; doi: 10.1080/02724634.2015.980505.

Carballido, J.L., Holwerda, F.M., Pol, D. \& Rauhut, O.W. 2017. An Early Jurassic sauropod tooth from Patagonia (Cañadón Asfalto Formation): Implications for sauropod diversity. Publicación Electrónica de La Asociación Paleontológica Argentina, 17, 50-57.

Casamiquela, R.M. 1963. Consideraciones acerca de Amygdalodon Cabrera (Sauropoda, Cetiosauridae) del Jurásico Medio de La Patagonia. Ameghiniana, 3, 79-95.

Chatterjee, S. \& Zheng, Z. 2002. Cranial anatomy of Shunosaurus, a basal sauropod dinosaur from the Middle Jurassic of China. Zoological Journal of the Linnean Society, 136, 145-169.

Cooper, M.R. 1984. A reassessment of Vulcanodon karibaensis Raath (Dinosauria: Saurischia) and the origin of the Sauropoda. Palaeontologia Africana, 25, 203-231.

Cox, B.M., Hudson, J.D. \& Martill, D.M. 1992. Lithostratigraphic nomenclature of the Oxford Clay (Jurassic). Proceedings of the Geologists' Association, 103, 343-345.

Cúneo, R., Ramezani, J., Scasso, R., Pol, D., Escapa, I., Zavattieri, A.M. \& Bowring, S.A. 2013. High-precision $\mathrm{U}-\mathrm{Pb}$ geochronology and a new chronostratigraphy for the Cañadón Asfalto Basin, Chubut, central Patagonia: Implications for terrestrial faunal and floral evolution in Jurassic. Gondwana Research, 24, 1267-1275; doi: 10.1016/j.gr.2013.01.010.

Dong, Z., Zhou, S.W. \& Zhang, Y. 1983. Dinosaurs from the Jurassic of Sichuan. Palaeontologica Sinica, New Series $C, 162,1-136$.

Goloboff, P.A. \& Catalano, S.A. 2016. TNT version 1.5 , including a full implementation of phylogenetic morphometrics. Cladistics, 32, 221-238; doi: 10.1111/ cla. 12160.

Goloboff, P.A. \& Szumik, C. A. 2015. Identifying unstable taxa: Efficient implementation of triplet-based measures of stability, and comparison with Phyutility and RogueNaRok. Molecular Phylogenetics and Evolution, 88, 93-104; doi: 10.1016/j.ympev.2015.04.003.

Goloboff, P.A., Farris, J.S. \& Nixon, K.C. 2008. TNT, a free program for phylogenetic analysis. Cladistics, 24, 774-786; doi: 10.1111/j.1096-0031.2008.00217.x. 
Harris, J.D. 2006. The significance of Suuwassea emilieae (Dinosauria: Sauropoda) for flagellicaudatan intrarelationships and evolution. Journal of Systematic Palaeontology, 4, 185-198; doi: 10.1017/ S1477201906001805.

Hauser, N., Cabaleri, N.G., Gallego, O.F., Monferran, M.D., Nieto, D.S. \& Armella, C. 2017. U-Pb and Lu-Hf zircon geochronology of the Cañadón Asfalto Basin, Chubut, Argentina: Implications for the magmatic evolution in central Patagonia. Journal of South American Earth Sciences, 78, 190-212; doi: 10.1016/j.jsames.2017.05.001.

He, X., Li, K., Cai, K. \& Gao, Y. 1984. Omeisaurus tianfuensis - a new species of Omeisaurus from Dashanpu, Zigong, Sichuan. Journal of Chengdu College Geology, Supplement, 2, 13-32.

He, X., Li, K. \& Cai, K. 1988. The Middle Jurassic Dinosaur Fauna from Dashanpu, Zigong, Sichuan. Vol. IV. Sauropod Dinosaurs (2) Omeisaurus tianfuensis. Sichuan Publishing House of Science and Technology, Chengdu, China.

Heathcote, J. \& Upchurch, P. 2003. The relationships of Cetiosauriscus stewarti (Dinosauria; Sauropoda): implications for sauropod phylogeny. Journal of Vertebrate Paleontology, 23 (Supplument 3), 60A.

Holwerda, F.M., Pol, D. \& Rauhut, O.W.M. 2015. Using dental enamel wrinkling to define sauropod tooth morphotypes from the Cañadón Asfalto Formation, Patagonia, Argentina. PLoS ONE, 10, e0118100; doi: 10.1371/journal.pone.0118100.

Jain, S.L. 1980. The continental lower Jurassic fauna from the Kota formation, India. Aspects of Vertebrate History: Museum of Northern Arizona Press, Flagstaff, 99-123.

Jain, S.L., Kutty, T.S., Roy-Chowdhury, T. \& Chatterjee, S. 1975. The sauropod dinosaur from the Lower Jurassic Kota formation of India. Proceedings of the Royal Society of London B: Biological Sciences, 188, 221-228; doi: 10.1098/rspb.1975.0014.

Knoll, F., Witmer, L.M., Ortega, F., Ridgely, R.C. \& SchwarzWings, D. 2012. The braincase of the basal sauropod dinosaur Spinophorosaurus and 3D reconstructions of the cranial endocast and inner ear. PLoS ONE, 7, e30060; doi: 10.1371/journal.pone.0030060.

Kutty, T.S., Chatterjee, S., Galton, P.M. \& Upchurch, P. 2007. Basal sauropodomorphs (Dinosauria: Saurischia) from the Lower Jurassic of India: their anatomy and relationships. Journal of Palaeontology, 81, 1218-1240; doi: 10.1666/04-074.1.

Lallensack, J.N., Klein, H., Milàn, J., Wings, O., Mateus, O. \& Clemmensen, L.B. 2017. Sauropodomorph dinosaur trackways from the Fleming Fjord Formation of East Greenland: Evidence for Late Triassic sauropods. Acta Palaeontologica Polonica, 62, 833-843; doi: 10.4202/ app.00374.2017.

Läng, É. 2008. Les cétiosaures (Dinosauria, Sauropoda) et les sauropodes du Jurassique moyen: révision systématique, nouvelles découvertes et implications phylogénétiques. $\mathrm{Ph} . \mathrm{D}$. Thesis. Centre de recherche sur la paléobiodiversité et les paléoenvironnements, Paris, France.
Läng, E. \& Mahammed, F. 2010. New anatomical data and phylogenetic relationships of Chebsaurus algeriensis (Dinosauria, Sauropoda) from the Middle Jurassic of Algeria. Historical Biology, 22, 142-164; doi: 10.1080/08912960903515570.

Liston, J.J. 2004a. A re-examination of a Middle Jurassic sauropod limb bone from the Bathonian of the Isle of Skye. Scottish Journal of Geology, 40, 119-122; doi: 10.1144/sjg40020119.

Liston, J.J. 2004b. "Clear as the difference between an arm and a leg?" A reexamination of the Skye sauropod discoveries. Quarterly Journal of the Dinosaur Society, 4, 18-21.

Maddison, W.P. \& Maddison, D.R. 2010. Mesquite: a modular system for evolutionary analysis. 2011; Version 2.75. https://www.cs.mcgill.ca/ birch/doc/mesquite/doc/ MesquiteManual.pdf.

Mannion, P.D. 2010. A revision of the sauropod dinosaur genus 'Bothriospondylus' with a redescription of the type material of the Middle Jurassic form ' $B$. madagascariensis'. Palaeontology, 53, 277-296; doi: 10.1111/j.1475-4983.2009.00919.x.

Mannion, P.D., Upchurch, P., Barnes, R.N. \& Mateus, O. 2013. Osteology of the Late Jurassic Portuguese sauropod dinosaur Lusotitan atalaiensis (Macronaria) and the evolutionary history of basal titanosauriforms. Zoological Journal of the Linnean Society, 168, 98-206; doi: 10.1111/ zoj. 12029.

McIntosh, J.S. 1990. Sauropoda. In: The Dinosauria (Weishampel, D.B., Dodson, P. \& Osmólska, H., eds). University of California Press. Berkeley, CA. 345-401.

McPhee, B.W., Yates, A.M., Choiniere, J.N. \& Abdala, F. 2014. The complete anatomy and phylogenetic relationships of Antetonitrus ingenipes (Sauropodiformes, Dinosauria): implications for the origins of Sauropoda. Zoological Journal of the Linnean Society, 171, 151-205; doi: 10.1111/zoj.12127.

McPhee, B.W., Bonnan, M.F., Yates, A.M., Neveling, J. \& Choiniere, J.N. 2015. A new basal sauropod from the pre-Toarcian Jurassic of South Africa: evidence of nichepartitioning at the sauropodomorph-sauropod boundary? Scientific Reports, 5. 13224; doi: 10.1038/srep13224.

McPhee, B.W., Upchurch, P., Mannion, P.D., Sullivan, C., Butler, R.J. \& Barrett, P.M. 2016. A revision of Sanpasaurus yaoi Young, 1944 from the Early Jurassic of China, and its relevance to the early evolution of Sauropoda (Dinosauria). PeerJ, 4, e2578; doi: 10.7717/ peerj.2578.

Moore, A., Xu, X. \& Clark, J. 2017. Anatomy and systematics of Klamelisaurus gobiensis, a mamenchisaurid sauropod from the Middle-Late Jurassic Shishugou Formation of China. Journal of Vertebrate Paleontology, Program and Abstracts, 37 (Supplement 2), 165A.

Noè, L.F., Liston, J.J. \& Chapman, S.D. 2010. 'Old bones, dry subject': the dinosaurs and pterosaur collected by Alfred Nicholson Leeds of Peterborough, England. Geological Society, London, Special Publications, 343, 49-77; doi: 10.1144/SP343.4. 
Ouyang, H. \& Ye, Y. 2002. The First Mamenchisaurian Skeleton with Complete Skull, Mamenchisaurus youngi. Sichuan Publishing House of Science and Technology. Chengdu, China.

Owen, R. 1841. Report on British Fossil Reptiles. R. and J.E. Taylor.

Owen, R. 1842. A description of a portion of the skeleton of Cetiosaurus, a gigantic extinct saurian occurring in the Oolitic Formation of different parts of England. Proceedings of the Geological Society of London, 3, 457-462; http://ci.nii.ac.jp/naid/10029480295/.

Peyer, K. \& Allain, R. 2010. A reconstruction of Tazoudasaurus naimi (Dinosauria, Sauropoda) from the late Early Jurassic of Morocco. Historical Biology, 22, 134-141; doi: 10.1080/08912960903562317.

Phillips, J. 1871. Geology of Oxford and the Valley of the Thames. Clarendon Press.

Pi, L., Ou, Y. \& Ye, Y. 1996. A new species of sauropod from Zigong, Sichuan, Mamenchisaurus youngi. Papers on Geosciences Contributed to the 30th International Geological Congress. 87-91.

Pol, D. \& Escapa, I.H. 2009. Unstable taxa in cladistic analysis: identification and the assessment of relevant characters. Cladistics, 25, 515-527; doi: 10.1111/j.10960031.2009.00258.x.

Pol, D. \& Rauhut, O.W.M. 2012. A Middle Jurassic abelisaurid from Patagonia and the early diversification of theropod dinosaurs. Proceedings of the Royal Society B: Biological Sciences, 279, 3170-3175; doi: 10.1098/rspb.2012.0660.

Pol, D., Rauhut, O.W.M. \& Carballido, J.L., 2009. Skull anatomy of a new basal eusauropod from the Cañadon Asfalto Formation (Middle Jurassic) of Central Patagonia. Journal of Vertebrate Paleontology, Program and Abstracts 29 (Supplement 3), 100A.

Pol, D., Garrido, A. \& Cerda, I.A. 2011. A new sauropodomorph dinosaur from the Early Jurassic of Patagonia and the origin and evolution of the sauropod-type sacrum. PloS One, 6:e14572; doi: 10.1371/journal.pone.0014572.

Raath, M.A. 1972. Fossil vertebrate studies in Rhodesia: a new dinosaur (Reptilia: Saurischia) from near the Trias-Jurassic boundary. Arnoldia (Rhodesia), 7, 1-7.

Racey, A. \& Goodall, J.G. 2009. Palynology and stratigraphy of the Mesozoic Khorat Group red bed sequences from Thailand. Geological Society, London, Special Publications, 315, 69-83; doi: 10.1144/SP315.6.

Rauhut, O.W.M. 2003a. A dentary of Patagosaurus (Sauropoda) from the Middle Jurassic of Patagonia. Ameghiniana, 40, 425-432.

Rauhut, O.W.M. 2003b. Revision of Amygdalodon patagonicus Cabrera, 1947 (Dinosauria, Sauropoda). Mitt. Museum Nat. kd. Berl., Geowiss. Reihe, 6, 173-181.

Remes, K., Ortega, F., Fierro, I., Joger, U., Kosma, R., Ferrer, J.M. \& Maga, A. 2009. A new basal sauropod dinosaur from the Middle Jurassic of Niger and the early evolution of Sauropoda. PLoS One, 4, e6924; doi: 10.1371/journal. pone.0006924.

Russell, D.A. \& Zheng, Z. 1993. A large mamenchisaurid from the Junggar Basin, Xinjiang, People's Republic of China.
Canadian Journal of Earth Sciences, 30, 2082-2095; doi: 10.1139/e93-180.

Suteethorn, S., Loeuff, J.L., Buffetaut, E., Suteethorn, V. \& Wongko, K. 2012. First evidence of a mamenchisaurid dinosaur from the Upper Jurassic-Lower Cretaceous Phu Kradung Formation of Thailand. Acta Palaeontologica Polonica, 58, 459-469; doi: 10.4202/app.2009.0155.

Tang, F., Jing, X., Kang, X. \& Zhang, G. 2001. Omeisaurus maoianus: a Complete Sauropod from Jingyuan, Sichuan. China Ocean Press, Beijing, China.

Taylor, M.P. 2010. Sauropod dinosaur research: a historical review. Geological Society, London, Special Publications, 343, 361-386; doi: 10.1144/SP343.22.

Upchurch, P. 1995. The evolutionary history of sauropod dinosaurs. Philosophical Transactions of the Royal Society of London. Series B: Biological Sciences, 349, 365-390; doi: 10.1098/rstb.1995.0125.

Upchurch, P. 1998. The phylogenetic relationships of sauropod dinosaurs. Zoological Journal of the Linnean Society, 124, 43-103; doi: 10.1006/zjls.1997.0138.

Upchurch, P. \& Martin, J. 2002. The Rutland Cetiosaurus: the anatomy and relationships of a Middle Jurassic British sauropod dinosaur. Palaeontology, 45, 1049-1074; doi: 10.1111/1475-4983.00275.

Upchurch, P. \& Martin, J. 2003. The anatomy and taxonomy of Cetiosaurus (Saurischia, Sauropoda) from the Middle Jurassic of England. Journal of Vertebrate Paleontology, 23, 208-231; doi: 10.1671/0272-4634(2003)23[208:TAATOC]2.0.CO;2.

Upchurch, P., Barrett, P.M. \& Dodson, P. 2004. Sauropoda. In: The Dinosauria (Weishampel, D.B, Dodson, P. \& Osmólska, H., eds.). Second Edition. University of California Press, Berkeley, CA. 259-322.

Upchurch, P., Martin, J. \& Taylor, M.P. 2009. Case 3472: Cetiosaurus Owen, 1841 (Dinosauria, Sauropoda): proposed conservation of usage by designation of Cetiosaurus oxoniensis Phillips, 1871 as the type species. Bulletin of Zoological Nomenclature, 66, 51-55; doi: 10.21805/bzn.v66il.a6.

Wang, J., Ye, Y., Pei, R., Tian, Y., Feng, C., Zheng, D. \& Chang, S.-C. 2018. Age of Jurassic basal sauropods in Sichuan, China: A reappraisal of basal sauropod evolution. Geological Society of America Bulletin, 130, 1493-1500; doi: 10.1130/B31910.1.

Wilson, J.A. 2002. Sauropod dinosaur phylogeny: critique and cladistic analysis. Zoological Journal of the Linnean Society, 136, 215-275; doi: 10.1046/j.10963642.2002.00029.x.

Wilson, J.A. 2005. Overview of sauropod phylogeny and evolution. The Sauropods: Evolution and Paleobiology, 15-49.

Wings, O., Schwarz-Wings, D. \& Fowler, D.W. 2011. New sauropod material from the Late Jurassic part of the Shishugou Formation (Junggar Basin, Xinjiang, NW China). Neues Jahrbuch Für Geologie Und PaläontologieAbhandlungen, 262, 129-150; doi: 10.1127/00777749/2011/0183.

Xing, L., Yong, Y.E., Chunkang, S.H.U., Guangzhao, P. \& Hailu, Y.O.U. 2009. Structure, orientation and finite 
element analysis of the tail club of Mamenchisaurus hochuanensis. Acta Geologica Sinica (English Edition), 83, 1031-1040; doi: 10.1111/j.1755-6724.2009.00134.x.

Xing, L., Miyashita, T., Zhang, J., Li, D., Ye, Y., Sekiya, T. \& Currie, P.J. 2015. A new sauropod dinosaur from the Late Jurassic of China and the diversity, distribution, and relationships of mamenchisaurids. Journal of Vertebrate Paleontology, 35, e889701; doi: 10.1080/02724634.2014.889701.

Yadagiri, P. 2001. The osteology of Kotasaurus yamanpalliensis, a sauropod dinosaur from the Early Jurassic Kota Formation of India. Journal of Vertebrate Paleontology, 21, 242-252; doi: 10.1671/0272-4634(2001)021[0242:TO OKYA]2.0.CO;2.

Young, C.-C. 1939. On a new sauropoda, with notes on other fragmentary reptiles from Szechuan. Bulletin of the Geological Society of China, 19, 279-315; doi: 10.1111/j.1755-6724.1939.mp19003005.x.

Young, C.-C. \& Zhao, X. 1972. Description of the type material of Mamenchisaurus hochuanensis. Institute of Vertebrate Paleontology and Paleoanthropology Monograph Series I, 8, 1-30.

Zhang, Y. 1988. The Middle Jurassic Dinosaur Fauna from Dashanpu, Zigong, Sichuan, Volume 1: Sauropod Dinosaur (I). Sichuan Publishing House of Science and Technology, Shunosaurus. Chengdu, China.

Zheng, Z. 1996. Cranial anatomy of Shunosaurus and Camarasaurus (Dinosauria: Sauropoda) and the phylogeny of the Sauropoda. Ph.D. Thesis. Texas Tech University, Lubbock, TX, USA. 